\title{
Situating moral education in a globalized world. Environmental ethical values and student experiences
}

Ole Andreas Kvamme, University of Oslo (o.a.kvamme@ils.uio.no)

\author{
Strand, T. (red.) Rethinking Ethical-Political Education. Dordrecht: Springer
}

\begin{abstract}
Since the 1980s the United Nations has called for a sustainable development, responding to the challenges of ecological crisis, global warming, and continuous social inequity. Within the sustainable development agenda environmental ethical values are addressed, formulated as concerns for human beings in the present and the future, and for the morethan-human world. These values are also central in UNESCO's initiative of education for sustainable development.
\end{abstract}

This chapter is an empirical study based on observations of a class of 10th grade Norwegian students who are exposed to the challenge of sustainable development in moral education. I examine how the environmental ethical values formulated by UNESCO are recontextualized in the classroom. The analyses are informed by critical cosmopolitanism, with a sensitivity for the situatedness of the students in a web of relations.

In the particular lesson in which sustainability is addressed, carbon footprint plays a significant role, drawing attention to the students' consumption patterns. In this way the issue becomes individualized and depoliticized, reflecting central tenets in neoliberalism. National concerns seem to add to this impact of hegemony.

Informed by a retrospect group interview, the article demonstrates the potential of bringing in the students' web of relations in moral education, addressing both their global and local embeddedness. An educational practice is suggested, in which the environmental ethical values are disclosed and explored, involving the students' situatedness, and mediating between the ethical and the political.

Key words: environmental and sustainability education; moral education; moral judgment; democratic iterations; critical cosmopolitanism

\section{Introduction and global context}

In autumn 2016, I observed Norwegian tenth grade students in a moral education class. Moral education is included in the Norwegian national curriculum, explicitly included in the syllabus of the school subject of Christianity, religion, philosophies of life, and ethics (CRLE). In this 
particular class moral education was taught in seven subsequent lessons. In one of these lessons, the challenge of sustainability was addressed through the teacher's lectures, teaching material, and class discussions. This is where my research interest is oriented, and this lesson is what this chapter deals with, where an analysis, interpretation, and discussion of what I observed are presented. ${ }^{1}$ However, before detailing the empirical study, the paper demands space to set the stage, present the relevant background, and make the necessary theoretical and methodological considerations.

\section{The emergence of environmental ethical values within the UN discourse}

Since the Industrial Revolution in late eighteenth-century England, the human impact on the earth has been overwhelming. The main characteristics of this time, often referred to as the era of the Anthropocene (Hamilton, Bonneuil, \& Gemenne, 2015) ${ }^{2}$, are ecological crises, mass extinction of species, and global warming.

For decades, the United Nations (UN) has acknowledged the severity of the current state of the earth. This acknowledgement was first demonstrated through the UN Conference on the Human Environment in Stockholm in 1972. Since the publication of the UN report Our Common Future (World Commission on Environment and Development, 1987), the continuous calls for societal change and transformation have been related to the key concept of sustainable development, which designates development in which human actions fulfill the needs of the present generation, acknowledge the limits of ecosystems, and do not compromise the ability of future generations to meet their needs. This concept has been conceived of as an attempt to create engagement that reduces global inequity and combats poverty while concurrently accommodating the conservation of nature (Le Grange, 2017). The three values addressed here-namely, concerns for present human beings, future human beings, and the more-than-human ${ }^{3}$ world-are expressed in numerous UN conventions (United Nations, 1948, 1992a, 1992b), and they are continuously referred to in the reports of the Intergovernmental Panel on Climate Change and the Intergovernmental Science-Policy Platform on Biodiversity and Ecosystem Services. These values are also pivotal to the 17 sustainable development goals that constitute the UN's 2030 Agenda (2015). The three values may be conceived of as environmental ethical values (Kronlid \& Öhman, 2013) that emphasize what is at stake - that life on earth is under threat in the present and future. These values are also positioned at the center of this chapter.

The environmental ethical values have emerged in the discourse of United Nations as responses to global threats. However, within this context, an ethical and political contradiction is

\footnotetext{
${ }^{1}$ Aspects of the empirical material presented here have, at a preliminary stage of the analysis, been published in an article that discusses the relationship between religious education and moral education (Kvamme, 2017).

${ }^{2}$ Crutzen and Stoermer (2000) suggest the industrial revolution as the starting point of the Anthropocene. At the moment, scholar opinion converges on 1945, coinciding with the outset of the great acceleration (Hamilton, Bonneuil, \& Gemenne, 2015, p. 1).

${ }^{3}$ The formulation "more-than-human world" is increasingly in use in scholarly literature (see e.g. Jickling, LotzSisitka, O'Donoghue, \& Ogbuigwe, 2006), evading the designation of the non-human as a negative opposite to what is human.
} 
established by the lack of sufficient societal transformations. Despite numerous declarations made by the world's nations since the early 1990s in relation to environmental ethical values, the sum of activities that harm and threaten to harm said values has increased dramatically during this period, thus establishing a contentious political field.

\section{A globalized world}

The global character of the current predicament is striking. Both the causes and consequences of the ecological crisis and global warming transcend borders (Attfield, 2015), thus representing environmental globalization (Papasthepanou, 2012). The crisis is not solely caused by economic globalization, but certainly exacerbated in a neoliberal form (Christoff \& Eckersley, 2013) characterized by rapid increase in production, consumption, and transport of commodities, resulting in both economic growth and global inequity. The UN's initiatives to deal with the crisis are also global and are instantiations of political globalization.

From an educational perspective, this global picture is overwhelming in its complexity. Educational systems have been central to national reproductions of social and cultural imaginaries of sovereign nation states (Rizvi \& Lingard, 2010). Today, this entity is challenged by a range of interconnectivities, including economic globalization and ecological crisis. Still, the nation state continues to be important, and education will continuously be local and particular in its concrete expressions. This complex situation comprises a background and context for the current study.

\section{The national context}

Norway has historically, during the $19^{\text {th }}$ century and into the $20^{\text {th }}$ century, been a net exporter of people, primarily to North America. Since the late 1960s, this situation has changed, with a growing number of immigrants. Between 1995 and 2011 the number of immigrants and descendants almost tripled, reaching 600000 out of 5 million (Eriksen, 2013). The majority of the $10^{\text {th }}$ grade students participating in this study, belongs to this group of descendants. They take part in a national school system, expressing the Nordic model, with an overall aim of equalizing social differences and promoting communal identities and loyalties (see Strand's introductory chapter of this volume).

After the Second World War, Norway, as a country positioned in Northern Europe, benefited from the considerable economic growth during the great acceleration (McNeill \& Engelke, 2014), and established a modern welfare state. When offshore petroleum production started in the 1970s, this country became one of the most affluent countries in the world. Norway's position as a petroleum producer coincided with the economic globalization, followed by the demand of increased energy supply, which Norway could provide ${ }^{4}$. On the other hand, Norway has, like the other Nordic countries, been an active contributor to the United Nations, most famously personally linked to the Norwegian prime minister Gro Harlem Brundtland leading the

\footnotetext{
${ }^{4}$ Norway is currently the $8^{\text {th }}$ largest producer of oil and the $3^{\text {rd }}$ largest producer of gas in the world, making the petroleum industry the country's largest industry (Ministry of Petroleum and Energy, 2019).
} 
commission presenting Our Common Future (WCED, 1987), establishing the UN sustainability agenda. An international engagement of solidarity, characterizing the nation's soul (Oxfeldt, 2017), is an inextricable aspect of Norwegian identity.

Consequently, Norway, even more strongly than most affluent countries, expresses the contradiction between acclaiming environmental ethical values, and contributing to the prolongation of unsustainable practices, pertinent to this study.

\section{Moral education and environmental ethical values}

Ethics or moral philosophy as a normative discipline is concerned with clarifying what is good and right (Darwall, 1998), also characterizing moral education as an educational practice. This concern is crucial for environmental and sustainability education. The normative element is widely acknowledged, e.g. listed as the first of five characteristics in Handbook of Research on Environmental Education (Stevenson, Broday, Dillon \& Wals, 2013, p. 2). Other studies within this field have explored values in educational settings (e.g. Öhman \& Östman, 2008; Pedersen, 2008; Manni, Sporre, \& Ottander, 2017), and even global values in Swedish curriculum (Sporre, 2017) and environmental ethical values in Australian curriculum (de Leo, 2012), supplemented by my own study of Norwegian curriculum and education policy documents (Kvamme, 2018). Here I found that although the humanities in general are barely included in educational initiatives on sustainability, the syllabus of CRLE, including moral education, nevertheless offers a space for environmental and sustainability education, pivotal as a background for the present study.

Although the normative aspects are widely acknowledged within the research field of environmental and sustainability education, there still seems to be a lack of research interest in how environmental ethical values are positioned in classroom interactions involving moral education. This is where the attention in the following is drawn.

\section{Theoretical considerations: Critical cosmopolitanism}

The specific purpose of this study is to explore how the environmental ethical values formulated within UNESCO's initiative of education for sustainable development are recontextualized in a Norwegian context of educational practices in moral education that addresses sustainability issues. This approach is qualified by perspectives from the moral philosopher and political theorist Seyla Benhabib.

With reference to Derrida (Benhabib, 2004, 2006), Benhabib emphasizes how iterations of universal claims always differ from the previous formulation, thus making conflict, plurality, and context visible. Benhabib designates the new formulations as democratic iterations, emphasizing that the conditions for these iterations may vary: They can be better or worse, more or less democratic, qualified by another concept, jurisgenerativity, drawn from Robert Cover (1983), signifying the interpretational space established by the universal claims in question.

In Situating the Self (1992), Benhabib criticizes the tendency in modern moral philosophy to position the moral subject outside of specific contexts. Benhabib emphasizes the significance of 
the concrete other embedded in a world of interdependency (Benhabib, 1992). She retains the possibility of ethical universalism, but starting from the situated self, within context. From Hannah Arendt, Benhabib draws the concepts of narrativity and enlarged thought, making context visible. While narrativity denotes the immersion of human action in a web of relations, enlarged thought includes the views of others in making moral judgments.

Benhabib's perspectives accommodate the dynamics distinguishing curriculum and educational practices, involving both bottom-up and top-down processes (see Ball, 1998). Other scholars have applied her concepts to educational studies (Wahlström, 2009; Vestøl, 2011; Sporre, 2015; Franck, 2017), and Vestøl in particular accentuates the relational aspect of Benhabib in studies of moral education. Below, the relational aspect is expressed in the multiple allegiances of the students, also instantiating Papestephanou's (2012) concept of eccentric cosmopolitanism.

The complexity of the recontextualizations of values in educational settings should be accounted for, with a sensitivity for the hidden curriculum (see Gress \& Purpel, 1988). Michael Apple has highlighted how conflict may illuminate "hidden imperatives built into situations that act to structure their actions" (2004, p. 92). According to Basil Bernstein, discourses are pedagogized when they are recontextualized in school settings. In this transformation, "there is a space in which ideology can play" (2000, p. 32). Both Apple's sensitivity for conflict and Bernstein's attention to ideology inform the analyses in this study.

Pertinent to the environmental ethical values involved in this study is the distinction between ideology and utopia, discussed by Ricoeur (2008). Here, ideology, in close affinity with hegemony, ${ }^{5}$ is conceived of as what sustains the current order, functioning as a resistance to the transformation of social relations that constitute domination. Utopia has the potential to question social reality. Here I explore the utopian dimension of the environmental ethical values, pondering the critical potential the values represent, creating possible alternatives to the current order, as expressed in the tradition of critical theory (Neupert-Doppler, 2018).

\section{Method and material}

The hallmark of qualitative research is to make specific contexts visible. This process has determined the present study, which explores recontextualizations of environmental ethical values in moral education. The study is an instantiation of reflexive methodology that ontologically assumes an external world while epistemologically acknowledging the involvement of interpretation in all aspects of the research process. Alvesson and Sköldberg (2009) identify four levels of interpretation; in the interaction with the empirical material; while considering underlying meanings of the material; as critical interpretation of ideology, power, and social reproduction; and in reflection on the text production. They suggest that reflexivity is involved when these levels are brought together. Such a practice of reflexivity may be

\footnotetext{
${ }^{5}$ Hegemony refers to the dominant culture that saturates the educational, economic, and social world (Apple, 2004).
} 
demonstrated with an example. At the outset, I limited the value scope to the concern for future generations and the more-than-human world. When encountering students with allegiances to various geographical, social, and political contexts, I realized that there were good reasons to include intragenerational concerns, left out at the outset, then warranted by a concern for a tight research design. Within the practice of reflexivity, this initial choice may be seen as enabled by the Norwegian (affluent) context, and, thus, as an instance of hegemony.

The interpretational practice is further deepened with reference to critical hermeneutics (Ricoeur, 1981). Unlike Gadamer (2004), Ricoeur includes the practice of distanciation in hermeneutical processes, emphasizing the practice of ideological critique and the sensitivity to textual structures and patterns. In this particular study, distanciation characterizes my positioning as a researcher. I was just to a minor extent taking part in the educational activities. Most of the lessons were recorded with video cameras, sometimes just with Dictaphones. The recordings relevant to the research topic were transcribed (Lippe, 2009a, cf. footnote 7, as well). In the analysis and interpretations, I distorted and questioned field notes, and transcripts. In the final discussion below the hermeneutical practice of appropriation is carried out, reflecting on the study's significance for moral education.

During the project, I conducted five semi-structured interviews (Brinkmann, 2018), all within the timeframe of 60 minutes. Two were conducted with the participating teacher, one with the school principal, one with the group of teachers responsible for this class, and one group interview with seven of the participating students. The interviews were recorded, the student interview with video camera, and the others with Dictaphone. All the recordings were transcribed by me, as is the case with the English translations presented in this chapter.

The analysis of this material has been conducted in two stages. In a preliminary study, I have studied how the environmental ethical values in question have appeared in the transcribed classroom interactions and interviews. ${ }^{6}$ This initial analysis forms the background, but the main concern has been to explore the recontextualizing processes in which the values are concealed, unpacked, disclosed. An analytical device is the identification of incidents that appear unusual and surprising, something that cannot prima facie be fully understood but seems to be "crystallizations of a problem related to the basic question" (Knauth, 2009, p. 24). ${ }^{7}$

\footnotetext{
${ }^{6} \mathrm{I}$ identified the presence of first-person singular / plural to express my or our needs, concerns, and identified intragenerational concern including the other in expressions of rich / poor / (un-)righteous / (un-)righteousness / (in-)just / (in-)justice / (in-)equality. In identifying references to the more-than-human world, I employed the words nature, environment, ecology, ecosystems, animals, and plants. Correspondingly, future generations have been identified by future, future generations, and coming generations. Other expressions have been considered and used, most significantly sustainable development.

${ }^{7}$ The transcription of recordings linked to the research interest, the strategy of recall in post-observation interviews, and the deployment of incident analysis are well-established procedures within qualitative research, here included with reference to the REDCo project, a major European research project in religious education (2006-2009) based on hermeneutic, reflective methodology (Lippe, 2009a, 2009b; Knauth, 2009; Weisse, 2010).
} 
All the participants in the classroom interactions and interviews were informed about the project beforehand, both orally and in writing, and all the participants gave voluntary, written consent, including the school principal and teachers involved. One out of the 26 students declined to participate, while three students had reservations to be video recorded, but allowed their voices to be included in the transcriptions. These four students were positioned in the upper-left corner of the classroom and were not video recorded. The students were 14 and 15 years old, and consent was obtained from one of their superiors as well as from the students. Personal information was anonymized when completing transcriptions of the recordings.

While fulfilling the requirements of the NSD Data Collection Services, ${ }^{8}$ there are aspects of the research design that deserve particular research ethical reflection. One concern pertains to the use of video recordings. The reservations made by some students to be video recorded - which the teacher believed was due to a reluctance for surveillance and control—demonstrate the strain that here is placed on educational practices. Due to technical problems, the lesson that is explored here was recorded solely by Dictaphones. Still I consider the transcriptions to be trustworthy. Because the study has not placed particular emphasis on the use of artifacts, gestures, and movements, it is justifiable to ask whether it was necessary to do video recordings at all.

The other concern addresses the fair treatment of the participating teacher. The teacher had a close relationship with the class and demonstrated exemplary teaching practices during the weeks of observations, establishing what emerged as a safe educational space. Still, regarding this particular lesson, the research approach makes aspects of the educational practice the starting point of a problematizing analysis determined by the perspectives of critical hermeneutics and critical cosmopolitanism. Hegemonic imaginaries are considered that transcend what supposedly may have been the deliberate intentions made by the teacher.

The following considerations should here be stated. First, a hermeneutical approach as conducted in the following, is distinguished by its awareness of the limitations of any research perspective. At some points below I suggest alternative interpretations of aspects of the material, demonstrating how other approaches may yield other results. Second, some of the teacher's exemplary practices are made distinct, but not all the constraints involved in non-ideal educational situations. For instance, during the observation period the teacher was assigned to follow up students on a scale far exceeding her working plan, due to the absence of colleagues and lack of qualified substitutes. And finally, it should be emphasized that the aim of this study has neither been to evaluate the manifold aspects of particular teaching practices nor to elucidate the deliberate intentions made by the teacher.

\section{Analyses and interpretations}

\footnotetext{
${ }^{8}$ In a Norwegian context, NSD Data Collection Service assesses whether research projects that process personal data meet the requirements of data protection legislation.
} 
From 9 September to 14 October 2016 I observed a tenth-grade class in moral education. The school is positioned in an urban setting in the south-east of Norway. I observed a total number of seven lessons. In the sixth lesson, sustainable development was addressed in whole class education, determining the teacher's lectures, the selection of teaching material, and the student discussions.

\section{Overview}

This key lesson consisted of five parts and started with a teacher introduction to the issue of sustainable development, followed by showing a documentary. Third comes a whole class discussion, fourth a short teacher lecture, ending up with students preparing for the written assignment that is to be continued the next lesson.

\begin{tabular}{|l|l|}
\hline $\begin{array}{l}\text { Duration } \\
\text { (minutes) }\end{array}$ & Part \\
\hline $17: 45$ & $\begin{array}{l}\text { Introduction: Sustainable development and carbon } \\
\text { footprint }\end{array}$ \\
\hline $29: 46$ & Documentary: Am I Guilty? \\
\hline $15: 09$ & Plenary discussion with the documentary as starting point \\
\hline $11: 06$ & Teacher's lecture: Ecosophy and philosopher Arne Næss \\
\hline $07: 33$ & Ending: Preparations for written assignment \\
\hline
\end{tabular}

In this lesson, all the environmental ethical values are made explicit at some point. In the introduction, the teacher defines sustainable development and addresses the issues of the environment and the future. While introducing the documentary, the teacher explains that the ecological footprint shows how sustainable development includes our present needs, the needs of future generations and the more-than-human world. Actually, the documentary does not exactly focus on the broader term of ecological footprint (Wackernagel \& Rees, 1998) but on the carbon footprint that relates to carbon dioxide $\left(\mathrm{CO}_{2}\right)$ emissions and greenhouse gases. ${ }^{9}$ Following the documentary, a plenary class discussion is held in which the students are engaged by the teacher. During this discussion, the more-than-human world is touched upon with regard to the consumption of meat and the status of cows. The students converse about the value of future generations, as well. In the final section of the lesson the intrinsic value of nature is briefly presented by the teacher with reference to ecosophy.

\section{Awareness of consumption patterns}

\footnotetext{
${ }^{9}$ This is a consumption-based emissions account, in contrast to more territorial accounts (West, Owen, Axelsson, \& West, 2016).
} 
Within the structure delineated above, the carbon footprint issue stands out as a decisive element of the entire lesson. It is the main focus of the documentary, and in the subsequent discussion in class, the emphasis placed on carbon footprints continues.

In the documentary, Am I Guilty? (Våge \& Holte, 2016), the carbon footprint of 24-year-old Sigbjørn is calculated by an expert. With the premise that the footprint should be of a size allowing all human beings to have equally big footprints, his carbon footprint is far too high. This assessment is followed by Sigbjørn's efforts to reduce his footprint, with implications for his transportation, food, and clothing. Then, the documentary deals with Sigbjørn's reflections as he realizes that he cannot meet a sustainable level. He is told by the expert that he has to move into an energy-efficient passive house, which Sigbjørn cannot afford.

In the plenary discussion following the screening of the documentary, its content is soon left behind, and the students' own consumption patterns and lifestyles are addressed and problematized.

From this perspective, the lesson accentuates the individual's ethical responsibility to adapt to a sustainable lifestyle. Thus, the contribution made by moral education encourages critical reflections on individual consumption patterns. Considering the previous lessons in this class focusing on moral dilemmas, with Heinz' dilemma employed as a recurrent example, the practice may be conceived of as a dilemma-driven moral education promoting moral reasoning. ${ }^{10}$ In this particular lesson, dilemmas are established by-from the universalizing perspective of carbon footprint — problematizing otherwise advantageous, favorable everyday practices.

While this positive contribution to an environmental and sustainability education should be acknowledged, what is conspicuous from the perspective of critical cosmopolitanism, is how the environmental ethical values in themselves are not made visible in the class room discussions, nor are the students' contexts, except when problematized. These aspects are to be further explored below.

\section{The exercise of the carbon footprint rule}

The discussion that follows the documentary is began by the teacher, who asks the students: "So, what do you think, is he [Sigbjørn] guilty?" Soon, the focus moves to the students' own practices. The discussion begins with one of the students, Saba, asking how one would travel to Bangladesh without an airplane. In the subsequent discussion, Saba adopts the leading position, but several of the students have similar questions, as their relatives also live far away. Waqas states that he does

\footnotetext{
${ }^{10}$ Heinz's wife is severely ill, and needs a medicine which is beyond reach, due to the high price set by the pharmacist who developed the medicine. Heinz' dilemma was made famous by Lawrence Kohlberg (Kohlberg \& Hersh, 1977) who in the 1970s developed the so-called moral reasoning approach within moral education. The emphasis is here laid on duty and justice, with the aim of developing moral reasoning through the consideration of moral dilemmas. Benhabib (1992) as introduced above, is criticizing Kohlberg for a lack of sensitivity for context, partly following objections raised by care-oriented feminist scholars (Gilligan, 1982; Noddings, 1984), but still upholding an interactive universalism. The observed lessons in this class deviate in some respects from Kohlberg's approach, but the emphasis on moral dilemmas is a common feature.
} 
not understand why one could not use an airplane to travel. From here on, the teacher maintains the focus on carbon footprint as a legitimate measure, questioned by the students, thus establishing a tug of war in a somewhat chaotic but still convivial classroom atmosphere. Saba contributes to this by contextualizing the issue at stake with reference to her own life, including her life in Bangladesh:

Saba: One cannot just stop travelling. I see my family in Bangladesh. I feel guilty if I don't visit them. Or not guilty...

Teacher: Saba, so your argument was...? [...] [Y]ou have a bad conscience if you don't go to Bangladesh. Then you have a bad conscience if you leave for Bangladesh, because you realize that your footprint is increasing.

Saba: You have to eat meat as well. That cow farts.

Students: (Laughing)

Saba: When it does, it pollutes a lot. I read something about cows polluting more than cars, or something like that. It was an article.

Anton: Do they fart that much?

Saba: (Laughs). Yes! But in Bangladesh, I have seen how much they poo and fart.

Students: (Laughing).

Waqas: I have never seen a cow fart in my life.

Saba: That is because you don't stand behind her!

Students: (Laughing).

Saba: I have a cow. That is different. I am sorry.

Teacher: Saba, your argument is...?

Students: (Laughing).

Saba: My argument is that if you eat a cow, isn't that good for society?

In assessing the action of flying to Bangladesh, Saba takes her family into consideration. This is how she expresses narrativity here - through the web of relations in which the action is immersed. Saba's maneuver may be seen as a way of avoiding the teacher's suggestion to include her carbon footprint in the moral judgment. Instead of confirming a moral dilemma Saba demonstrates how the carbon footprint rule may be played with, thus making the calculations ridiculous. At the same time, she also introduces first-hand knowledge of life in Bangladesh and 
her family ties here. In this, Saba connects the feeling of guilt with her familial obligations. As a practice of enlarged thought, Saba is prioritizing her family as a moral concern.

In one respect, this analysis does not shed much light on the position of the environmental ethical values in question, the concerns for the more-than-human world, or the present and future generations. These values may be viewed as being tied up in the carbon footprint itself, stated as a universal claim, which, based on the documentary, may be formulated as a moral rule in the following way: The consumption of an individual human being should not exceed the concomitant amount of greenhouse gases produced directly and indirectly and equivalent to 1.5 tons of $\mathrm{CO}_{2}$.

In the lesson's introduction, the teacher maintains that the footprint specifies what sustainable development is about, addressing the concerns for future generations and the-more-than-human world. Our present needs are mentioned, but global intragenerational justice is not addressed, and the rationale behind the carbon footprint rule is not disclosed, neither in the film nor in the classroom discussion. Because of this, the rule may be said to reduce the jurisgenerative capacity of the values in question rather than encouraging democratic iterations. The carbon footprint rule stands out as a version of the Kantian position (i.e., a universal rule under which the particulars are subsumed) that Benhabib is criticizing.

This impression is both modified and confirmed by the inclusion of ecosophy in the final part of the lesson. The teacher seems to refer to a philosophical position that expresses a relational perspective on the human-nature relationship and the intrinsic value of nature:

Teacher: I know that you are tired now, but please pay attention. [...] We are a totality, right? For Arne Næss, this applies not just to human beings, right? It concerns plants, animals, all life. We are the same totality, right? And he is concerned with non-violence. Then, he does not just refer to war between people, but violence against nature, right? Pollution is violence against nature. Do you agree?

Several students: Yes.

The teacher seeks support from the students, which she receives in the final statement that references Næss. While this consent may be seen as democratic, the situation is characterized by a familiar restriction in educational settings - that of time running out. The jurisgenerative capacity of the educational situation established here may then be considered quite limited.

Said this, the playful tug of war between the teacher and students during the lesson may in itself be conceived of as the enactment of democratic iterations, because the students are not passively subsuming under the carbon footprint rule itself. The frictions, disagreements, and play with the rule are part of the iterations, accommodated by the teacher. From this point of view, it is relevant that the students themselves situate the discussion in their own life and web of relations. 


\section{Eccentric selves}

A salient contrast emerges in this lesson. On the one hand, a concern for present human beings involving distant others (i.e., intragenerational justice) is not addressed, although often included in the sustainability agenda (WCED, 1987; United Nations, 2015). On the other hand, many of the students themselves are related to people living in places where the living conditions are very different from what the students experience in the Norwegian context. We have already seen Saba illustrating this global situatedness in a distinct way. Saba, an urban Norwegian, owns a cow in Bangladesh, thus expressing a personal embeddedness within this Bangladeshian context. In the group interview following the observation period, several students share similar experiences and knowledge. In other words, the students in this class represent knowledge and experiences of the concrete other, which, according to Benhabib (1992), is decisive for moral judgment. However, it is not just a question of knowledge and resources. For Saba, it is a question of relations and commitment. The narrativity of her self includes her allegiances to Bangladesh. Such manifold relationships are what Papastephanou (2012) refers to with the concept of eccentric circles that question the notion of a local, unified self that is nicely positioned in the center of concentric circles. Relationships to geographically distanced others may be strong and pivotal among the self's multiple allegiances (Papastephanou, 2012, p. 24).

However, the multiple allegiances that the students experience are not necessarily global in character. They are also local, concerning Norwegian family and friends, and even expressed in their relatedness to the more-than-human world. In this lesson, the students were not invited to explore this aspect of their situatedness, but in the subsequent group interview, they were asked whether they had a place in nature that was of particular importance to them. Most of the students responded positively, with Omar being the one to come forward.

Omar: Yes, I do.

Interviewer: Where is that?

Omar: I will tell you. [The other students laugh.] It is not where I live, but, you know, near a town 30 kilometers away. There is a small river there. I can drink the water. Everyone can do that. I didn't even know about it. I had to walk the dog, which I don't like to do any longer. [The other students laugh.] After that episode, the dog started to love me because I was there. Then it was the river, and I started to drink from the river. And the river is really beautiful. People come there and take photos.

Interviewer: Why is it a special place for you?

Omar: It is still there, I hope.

Interviewer: So, if somebody came by and said: "I am going to build a huge shopping center there..."? 
Omar: Then I will reject that.

Marjori: But do you believe this is something you can decide? I don't mean to be rude.

Omar: It is all the memories that are there. I will always remember what my mother has done to me, then.

The river is a place that is accessible to all; it is a place that made the dog love Omar and gives rise to memories of his mother. Omar also believes that it is a place that should be protected from human intervention, and here Omar speaks with authority, making a claim with both ethical and political reverberations. Still, there seems to be something about the place that is difficult for Omar to articulate - something beyond the beauty of the river. This aspect of his eccentric self, which also involves an element of otherness that values the more-than-human world, seems to apply to moral education when engaged in environmental ethical values.

\section{Hegemony and ideology}

In recontextualizations involving educational structures, ideology makes an impact (Bernstein, 2000), also characterizing contentious and conflicting situations (Apple, 2004) in which hegemonic order is maintained. These perspectives pertain to this school lesson through an individual emphasis and a possible impact of national boundaries.

When Waqas states that the carbon footprint calculation doesn't make sense to him ("Why not just take an airplane?") and Saba holds that meat should be eaten as a way of reducing the number of cows and, consequently, the amount of greenhouse gas emissions, the teacher finds it necessary to defend the market law of supply and demand. The carbon footprint rule here functions as an introduction to the laws of a market economy, thus educating sustainable consumers.

This pattern is consolidated by the consistent individual perspective on sustainability issues established during the lesson, only expanded shortly at the end. Political processes that determine the conditions for living sustainable lives are not brought in, and there is no reference to Norway's role in the world economy as a prominent producer of oil and gas. The emphasis on individual responsibility demonstrated in this lesson, distinguishes dominant approaches within moral education (Halstead \& Pike, 2006), both the previous mentioned moral reasoning approach (cf. footnote 10) and the value clarification approach (Raths, Harmin, \& Simon, 1966). In that way this lesson may be said to instantiate a central feature of moral education.

However, to pose the sustainability challenge as a predominantly individual concern solved within a market economy may also be seen to support basic tenets of neoliberalism (Rizvi \& Lingard, 2010; Peters, 2011). The lesson illustrates a concern raised by Huckle and Wals regarding the educational employment of ecological footprints that may "unwillingly contribute to a false consciousness engendered by ideology and hegemony, while leaving existing structures of power intact" $(2015$, p. 502). 
In the interview with the teacher carried out in retrospect, I was curious about her reflections on the absence of a societal and political perspective. She referred to the limited time available and shared a concern for distinguishing between moral education and social science. However, she also added:

I would very much like to position these issues in the larger picture. Obviously, ethics is just not valid on an individual level. Then it turns out to be just a thought experiment. If they [the students] are to apply ethics in their own lives they are living in a society and within a context. It is here they need the tool that ethics should be. It should be applicable to such a purpose. And I haven't taught them to do that, really.

In these considerations, the teacher suggests that grounds exist for more of an inclusion of the students' societal and political situatedness in moral education.

Hegemony may also be studied in connection with the impact of national imaginaries and boundaries. In a key scene in the documentary, Sigbjørn summarizes his impressions of a Danish eco-village he visited, stating: "If my friends see this, they do have to realize that it is completely possible to live sustainably and still have a really good life." (Våge \& Holte, 2016). A community complying with the carbon footprint rule is a rare instance in the documentary. In this context, Saba's immediate comment about living sustainably in Bangladesh is significant. She is never challenged to qualify this statement, neither by her teacher nor by her fellow students. Still, in this study, the single comment made by Saba here is of prime interest, not because what it signifies is obvious, but because the reply turns to pivotal questions: What does Saba mean? What kind of experiences is she referring to? What kind of knowledge is this based on?

I recalled Saba's statement in the interview with the teacher, who recognized the student: "I noticed it at once when she came up with this, because the statement is so incredibly comprehensive." She expressed difficulties with grappling the meaning, but instead went on with referring to Saba's preference for her life in Bangladesh and her wish to live there as an adult. The teacher had challenged this statement with reference to how Norway provides Saba with free education without benefiting from this investment if she moves to another country. However, Saba's reply satisfied the teacher: She plans to be a physician in Bangladesh, a nation with a shortage of health workers.

From one perspective this account expresses this teacher's capability to establish confident relationships with her students and in a Socratic manner encouraging them to examine their lives. From the perspective of critical hermeneutics adopted here, this particular instance stands out as part of a larger societal project of equity, integrating multicultural Norwegian students to a future life in Norway, in conformity with the comprehensive school system expressing the Nordic model (Strand, in the introductory chapter of this volume). This project is well-grounded, but at the same time and in this case, certain hegemonic boundaries become visible. 
When Saba argues that her Norwegian education is needed in Bangladesh, the teacher is ready to give her approval. In this way the pattern of an asymmetrical relationship-with the privileged supplying health aid to the unprivileged - is confirmed. With reference to the national imaginaries presented previously in this chapter, Saba may be said to enter the role of the nation's soul, here demonstrating a Norwegian solidarity with those in need (Oxfeldt, 2017. ${ }^{11}$ ) However, in this particular lesson Saba's line of thought follows the opposite direction; within a sustainability perspective her life in Bangladesh seems to represent exemplary qualities pertinent to an unsustainable Norwegian life. ${ }^{12}$

Following up on the issue of hegemony and ideology, the utopian dimension of the environmental ethical values turns significant. To recall, utopia expresses the potential to question social reality and the current order, while ideology is what sustains the status quo (Ricoeur, 2008). The school lesson in question illustrates how an individual focus may rule out the utopian function of the environmental ethical values. It should be added that Sigbjørn, in the documentary, questions societal structures when he cannot comply with a sustainable carbon footprint. This instance of mediation between the individual level and the societal and political level is not reflected in the classroom interactions.

The individual outlook even includes a scene in the class when the value of future generations is subject to controversy among the students. This is a distinct recontextualization of this value. Lydia holds that the world does not change if a child turns vegetarian, with support from Waqas. Maria, Anton, Saba, and Mona, on the other hand, insist that it does make a difference, with Saba stating that "The children are the future" and Mona holding that "I won't have a future if I go on like this." Here, then, the environmental ethical value is appropriated by some of the students, but the focus is still individualistic and concerns a moral responsibility for private consumption.

In addition to the potential of ideology critique, the utopian element also opens up possible alternatives to the current order (Neupert-Doppler, 2018), and again, the documentary explores other examples, mainly the Danish eco-village. This realized utopia is not a reference in the subsequent classroom discussion. Even more significant, the utopian element is not explored with reference to the students' multiple allegiances.

I raised Saba's statement in the group interview with the students (Saba was not among them). Six out of the seven students had relatives in other parts of the world. They identified the statement at once and conducted various reflections that were based on their own experiences. There were

\footnotetext{
${ }^{11}$ Oxfeldt (2017) interprets the Norwegian high school-drama series Skam as a national allegory, and the character Noora as an expression of the nation's soul.

12 This interpretation should not be seen as a reconstruction of deliberate intentions made by the teacher, but as an exploration of the impact of hegemonic boundaries. (The omission of intragenerational concerns from the original research design, accounted for above in the section on method, makes another case).
} 
references to a circular economy, where neighbors borrowed and exchanged goods and services, and they reported experiences of living with nature, not against nature.

However, the students also problematized Saba's claim, stating that the use of wood and gas for heating constituted a considerable environmental problem in many places. One of the students had relatives who were quite rich with consumption patterns that were comparable to her family in Norway. In general, a nuanced picture emerged through the students' comments, and the utopian potential of the environmental ethical values was explored and exemplified. It offered critical perspectives and opened up new possibilities based on the students' multiple allegiances.

A striking element in this group interview is the concern for justice-this was continuously brought up by the students themselves but was conspicuous because it was not addressed in the school lesson. In one instance, the students discussed possible future scenarios of climate change. Several students reported on their own experiences of climate change, with Marjori stating: "People die already in India due to the heat." I asked whether this kind of knowledge could be included in moral education.

Waqas, Amit, and Omar: Yes.

Aisha: Yes, of course.

Marjori: Because it is our fault that it is so hot there.

Waqas: Or not our fault...

Marjori: The rich part of the world. We are the ones who pollute the most.

When Marjori confirms the approval made by her fellow students, she uses the perspective of personal responsibility but makes the utopian and critical element visible with reference to global justice.

\section{Final discussion and concluding remarks}

In this study, I have explored the recontextualizations of environmental ethical values in moral education lesson focusing on the concern for present and future human beings and the morethan-human world.

The analyses and interpretations have been anchored within critical hermeneutics that emphasizes ideology critique and the significance of context. Critical cosmopolitanism has been employed to explore the mediations between universal claimed values and specific contexts. I have proposed that the environmental ethical values are distinguished with a utopian dimension, which expresses potential for the critique of the hegemonic order and the exploration of possible alternative worlds. 
In the moral education lesson in question, the major contribution to environmental and sustainability education seems to be to challenge the students' individual consumption patterns with reference to their carbon footprints. The interactions between the teacher and students are guided by an emphasis on individual responsibility, in itself reflecting a typical position within moral education. In this case responsible consumer behavior is promoted while problematizing the students' contexts.

It does not follow from this study that personal responsibility should be dismissed as a vital concern in moral education. And processes of universalization should not be ruled out in environmental and sustainability education. Still, in this study an unambiguous individual perspective has been problematized, quite simply because it does not take the situatedness of the students into account. In this way, vital aspects of the students' selves are not employed as resources in the educational discourse.

Thus, from the perspective of critical cosmopolitanism certain limitations of this instance of moral education has been discussed. The environmental ethical values in question seem to be tied up in a carbon footprint rule, which lays restrictions on the jurisgenerativity and the exercise of democratic iterations. The students themselves become generalized others, and the others who are influenced by their consumption patterns disappear. Morally significant relations that involve the students' eccentric selves are not accentuated. In these ways, the utopian functions of the environmental ethical values are restricted in terms of the potential for critique of the current order, here conceived of as neoliberal tenets and national boundaries, and alternative life practices and communities are not explored.

These patterns are not unique. Hume and Barry (2015) address the tendency to view the student as an individual actor as one of the main criticisms of education for sustainable development ( $p$. 735), quoting Scott and Gough (2010), who address the neglect of "the student as a social and more public actor" (p. 3737). Huckle and Wals (2015) report on similar tendencies in their study of the UN's Decade of Education for Sustainable Development. In her study on civic education, Schindel Dimick (2015) identifies how consumption is conceived of as merely an individual concern.

However, the present study also demonstrates the potential of the students' situatedness as a resource in moral education on sustainability. This potential has become visible by concepts such as the web of relations (Benhabib, 1992) and eccentric allegiances (Papastephanou, 2012). In the classroom discussion and the subsequent group interview the students reveal these multiple allegiances - their relatedness to the more-than-human world and their relatives, places, and life practices in other parts of the world. The situatedness represent experience and knowledge with converging relevance for all of the three environmental ethical values addressed above.

A possible future direction for moral education in terms of this study, would be to further explore this situatedness considering practices of mediations - between the personal and the political, the 
private and the public, and the local and the global. In such meditations which should accommodate the integrity of the students, both tensions, inconsistencies, and disagreements may become visible, opening up spaces for the critical and constructive utopian employment of environmental ethical values. Within such a scope, the question of what distinguishes a good society-locally, nationally, and globally - becomes equally as important as what distinguishes the morally right individual action. This might also be a good place to pedagogically, ethically, and politically struggle with the main contradiction in the sustainability agenda, constituted by proclaimed values and insufficient action.

\section{References}

Alvesson, M. \& Sköldberg, K. (2009). Reflexive methodology: New vistas for qualitative research. London: Sage.

Apple, M. (2004). Ideology and curriculum. New York: Routledge.

Attfield, R. (2015). The ethics of the global environment. Edinburgh: Edinburgh University Press.

Ball, S. (1998). Big policies/small world: An introduction to international perspectives in education policy. Comparative Education, 34 (2), 119-130.

Benhabib, S. (1992). Situating the self. Cambridge: Polity Press.

Benhabib, S. (2004). The rights of others: aliens, residents, and citizens. Cambridge: Cambridge University Press.

Benhabib, S. (2006). Another cosmopolitanism. Oxford: Oxford University Press.

Bernstein, B. (2000). Pedagogy, symbolic control and identity: Theory, research, critique. Lanham, MD: Rowman \& Littlefield.

Brinkmann, S. (2018). The interview. In N. Denzin \& Y. S. Lincoln (Eds), The Sage handbook of qualitative research (pp. 576 - 599). London: Sage Publications Ltd.

Christoff, P. \& Eckersley, R. (2013). Globalization and the environment. Lanham, MD: Rowman \& Littlefield.

Cover, R.M. (1983). The Supreme Court 1982 Term: foreword: nomos and narrative, Harvard Law Review, 97(4), 4-68. Retrieved from https://www.depauw.edu/site/humanimalia/issue\%2017/pdfs/The\%20Supreme\%20Court $\% 201982 \% 20$ Term\%20--\%20Foreword_\%20Nomos\%20and\%20Narrative.pdf

Crutzen, P. J. \& Stoermer, E. F. (2000). The Anthropocene: An epoch of our making. Global Change Newsletter, 41, $17-18$.

Darwall, S. (1998). Philosophical ethics. Boulder, CO: Westview Press.

De Leo, J. (2012). The global values within education for sustainable development. A case study of education for sustainable development in the Australian national curriculum (Doctoral dissertation). The University of Adelaide.

Eriksen, T. H. (2013). Immigration and national identity in Norway. Washington, DC: Migration Policy Institute. 
Franck, O. (2017). Challenging the teaching of global ethical unity: Religious ethical claims as democratic iterations within sustainability didactics. Journal of Education for Sustainable Development, 11(1), 1-13.

Gadamer, H.-G. (2004). Truth and method. London: Continuum

Gilligan, C. (1982). In a Different Voice. Psychological Theory and Women's Development. Cambridge, MA: Harvard University Press.

Gress, J. R. \& Purpel, D. E. (1988). Curriculum: An introduction to the field. Berkeley, CA: McCutchan.

Halstead, M., \& Pike, M. (2006). Citizenship and moral education: Values in action. London: Routledge.

Hamilton, C., Bonneuil, C., \& Gemenne, F. (Eds) (2015). The Anthropocene and the global environmental crisis. Rethinking modernity in a new epoch. New York: Routeledge.

Huckle, J. \& Wals, A. E. J. (2015). The UN decade of education for sustainable development: Business as usual in the end. Environmental Education Research, 21(3), 491-505.

Hume, T. \& Barry, J. (2015). Environmental education and education for sustainable development. In N. J. Smelser \& P. B. Baltes (Eds), International encyclopedia of the social \& behavioral sciences (pp. 733-739). Amsterdam: Elsevier.

Jickling, B., Lotz-Sisitka, H., O’Donoghue, R. \& Ogbuigwe, A. (2006) Environmental Education, Ethics \& Action: A Workbook to Get Started. Nairobi: UNEP.

Knauth, T. (2009). Incident analysis - a key category of REDCo classroom analysis. Theoretical background and conceptual remarks. In I. Ter Avest, D. P. Jozsa, T. Knauth, J. Rosón, \& G. Skeie (Eds). Dialogue and conflict on religion. Studies of classroom interaction in European countries (pp. 28-40). Münster: Waxmann Verlag.

Kohlberg, L. \& Hersh, R. H. (1977). Moral Development: A Review of the Theory. Theory into Practice 16(2), 53-59.

Kronlid, D. \& Öhman, J. (2013). An environmental ethical conceptual framework for research on sustainability and environmental education. Environmental Education Research, 19(1), $20-44$.

Kvamme, O. (2017). The significance of context: Moral education and religious education facing the challenge of sustainability. Discourse and Communication for Sustainable Education, 8(2), pp. 24-37.

Kvamme, O. (2018). Blurring the image of the other? The recontextualization of environmental ethical values in Norwegian education policy documents. In J. Ristiniemi, G. Skeie, \& K. Sporre (Eds), Challenging life. Existential questions as a resource for education (pp. 359-381). Münster: Waxmann Verlag.

Le Grange, L. (2017). Environmental Education After Sustainability. In B. Jickling \& S. Sterling (Eds.). Post-Sustainability and Environmental Education (pp. 93-107). Basingstoke: Palgrave Macmillan. 
Lippe, M. von der (2009a). Hermeneutic video analysis in ethnographic research. In I. Ter Avest, D.-P. Jozsa, T. Knauth, J. Rosón, \& G. Skeie (Eds.), Dialogue and conflict on religion. Studies of classroom interaction in European countries. Münster: Waxmann Verlag.

Lippe, M. von der (2009b). Scenes from a classroom. Video analysis of classroom interaction in religious education in Norway. In I. Ter Avest, D. P. Jozsa, T. Knatuh, J. Rosón, \& G. Skeie (eds.), Dialogue and conflict on religion. Studies of classroom interaction in European countries (pp. 174-193). Münster: Waxmann Verlag.

Manni, A., Sporre, K., \& Ottander, C. (2017). Emotions and values - a case study of meaningmaking in ESE. Environmental Education Research, 23(4), 451-464. DOI: 10.1080/13504622.2016.1175549.

Ministry of Education and research. (2005). The Syllabus of Christianity, Religion and Philosophies of Life. Retrieved from: https://www.udir.no/Lareplaner/

Ministry of Petroleum and Energy. (2019). Oil and Gas. Retrieved from https://www.regjeringen.no/en/topics/energy/oil-and-gas/id1003/

Neupert-Doppler, A. (2018). Critical Theory and Utopian Thought. In B. Best, W. Bonefeld, \& C. O’Kane (eds.), The SAGE Handbook of Frankfurt School Critical Theory. Volume 1 (pp. 714-732), Los Angeles: SAGE reference.

Noddings, N. (1984). Caring: a feminine approach to ethics \& moral education. Berkeley, CA: University of California Press.

Oxfeldt, E. (2017). Noora som verdensredder og feminist I NRK-serien Skam [Noora as a world savior and feminist in the Norwegian web drama series Skam]. In E. Oxfeldt \& J. Bakken (eds.), Open doors to the world. Norwegian youths' encounter with narratives of guilt and priviliges [Åpne dфrer mot verden. Norske ungdommers mote med fortellinger om skyld og privilegier] (pp. 47-64). Oslo: Scandinavian University Press. DOI: 10.18261/9788215030227-2017-04

Papastephanou, M. (2012). Thinking differently about cosmopolitanism. Theory, eccentricity, and the globalized world. Boulder, CO: Paradigm Publishers.

Pedersen, H. (2008). "We have to kill the animals so that they won't die!" Classroom discussions about hunting as a dimension of ESD. In J. Öhman (ed.), Values and democracy in education for sustainable development - Contributions from Swedish research (pp. 145-164). Malmö: Liber.

Raths, L. E., Harmin, M., \& Simon, S. B. (1966). Values and teaching: working with values in the classroom. Columbus, $\mathrm{OH}$ : Merrill.

Ricoeur, P. (1981). Hermeneutics and the human sciences. Cambridge: Cambridge University Press.

Ricoeur, P. (2008). Ideology and utopia. In P. Ricoeur (Ed.), From text to action. Essays in hermeneutics II (pp. 300-316). London: Continuum. 
Rizvi, F. \& Lingard, B. (2010). Globalizing education policy. Abingdon: Routledge.

Scott, A. H. \& Gough, S. (2010). Sustainability, learning and capability: Exploring questions of balance. Sustainability, 2, 3735-3746. DOI:10.3390/su2123735.

Schindel Dimick, A. (2015). Supporting youth to develop environmental citizenship within/against a neoliberal context. Environmental Education Research, 21(3), 390-402. DOI: $10.1080 / 13504622.2014 .994164$.

Sporre, K. (2015). In search of human dignity: Essays in theology, ethics and education. Münster: Waxmann Verlag.

Sporre, K. (2017). Global Responsibilities and Ethics Education: To Be Assessed and If So How? In O. Franck, (ed.), Assessment in Ethics Education. A case of National Tests in Religious Education (pp. 115-143). Cham: Springer.

Stevenson, R. B., Brody, M., Dillon, J., \& Wals, A. E. J. (2013). Introduction. In R. B. Stevenson, M. Brody, J. Dillon, \& A. E. J. Wals (Eds.), International handbook of research on environmental education (pp. 1-7). New York/London: Routledge.

UNESCO (2004). The UNDESD international implementation scheme. Retrieved from http://unesdoc.unesco.org/images/0013/001399/139937e.pdf

UNESCO (2006). Framework for the DESD draft implementation scheme. Retrieved from https://unesdoc.unesco.org/ark:/48223/pf0000148650

Våge, H. C. \& Holte, S. (2016). Skyldig, jeg? [Am I Guilty?] [Documentary]. NRK. Retrieved from https://p3.no/dokumentar/skyldig-jeg/

United Nations (UN). (1948). Universal Declaration of Human Rights. Retrieved from https://www.un.org/en/universal-declaration-human-rights/

United Nations (UN). (1992a). United Nations Framework Convention on Climate Change. Retrieved from https://unfccc.int/resource/docs/convkp/conveng.pdf

United Nations (UN). (1992b). The Convention on Biological Diversity. https://www.cbd.int/convention/text/default.shtml

United Nations General Assembly (2015). Resolution 70/1. Transforming our world: The 2030 agenda for sustainable development. Retrieved from https://www.un.org/en/development/desa/population/migration/generalassembly/docs/glo balcompact/A_RES_70_1_E.pdf

Vestøl, J. M. (2011). Moral education and the role of cultural tools. Journal of Moral Education, $40(1), 37-50$.

Wackernagel, M. \& Rees, W. (1998). Our ecological footprint. Reducing human impact on the earth. Gabriola Island: New Society Publishers.

Wahlström, N. (2009). Understanding the universal right to education as jurisgenerative politics and democratic iterations. European Educational Research Journal, 8(4), 520-533.

Weisse, W. (2010) REDCo: A European research project on religion in education. Religion \& Education, 37(3), 187-202. DOI: 10.1080/15507394.2010.513937

West, S. E., Owen, A., Axelsson, K., \& West, C. D. (2016). Evaluating the use of a carbon footprint calculator: Communicating impacts of consumption at household level and 
exploring mitigation options. Journal of Industrial Ecology, 20(3), 396-409. DOI: https://doi.org/10.1111/jiec.12372.

World Commission on Environment and Development (WCED). (1987). Our Common Future. Retrieved from http://www.un-documents.net/our-common-future.pdf

Öhman, J. \& Östman, L. (2008). Clarifying the ethical tendency in ESD practice: A Wittgenstein-inspired approach. Canadian Journal of Environmental Education, 13(1), $57-72$. 